\title{
Proliferation of sorted human and rat beta cells
}

\author{
G. Parnaud • D. Bosco • T. Berney • F. Pattou • \\ J. Kerr-Conte $\cdot$ M. Y. Donath • C. Bruun • \\ T. Mandrup-Poulsen • N. Billestrup • P. A. Halban
}

Received: 23 May 2007 / Accepted: 18 September 2007 / Published online: 10 November 2007

(C) Springer-Verlag 2007

\begin{abstract}
Aims/hypothesis The aim of the study was to determine whether purified beta cells can replicate in vitro and whether this is enhanced by extracellular matrix (ECM) and growth factors.

Methods Human beta cells were purified by FACS by virtue of their high zinc content using Newport Green, and excluding
\end{abstract}

Electronic supplementary material The online version of this article (doi:10.1007/s00125-007-0855-1) contains supplementary material, which is available to authorised users.

G. Parnaud $(\bowtie) \cdot$ P. A. Halban

Department of Genetic Medicine and Development,

University Medical Center,

1 rue Michel-Servet,

1211 Geneva-4, Switzerland

e-mail: geraldine.parnaud@medecine.unige.ch

D. Bosco $\cdot$ T. Berney

Cell Isolation and Transplantation Center,

Division of Surgical Research,

Department of Surgery, University Hospital,

Geneva, Switzerland

F. Pattou $\cdot$ J. Kerr-Conte

Department of Surgery, INSERM U859,

Lille 2 University,

Lille, France

M. Y. Donath

Division of Endocrinology and Diabetes, Internal Medicine,

Zurich, Switzerland

C. Bruun · T. Mandrup-Poulsen • N. Billestrup

Steno Diabetes Center,

Gentofte, Denmark

T. Mandrup-Poulsen

Department of Molecular Medicine, Karolinska Institutet,

Stockholm, Sweden ductal and dead cells. Rat beta cells were sorted by autofluorescence or using the same method developed for human cells. Cells were plated on poly-L-lysine or ECMs from rat or human bladder carcinoma cells or bovine corneal ECM and incubated in the presence of BrdU with or without growth factors.

Results The newly developed method for sorting human beta cells yields a population containing $91.4 \pm 2.8 \%$ insulinpositive cells with a low level of spontaneous apoptosis and a robust secretory response to glucose. Beta cells from 8week-old rats proliferated in culture and this was increased by ECM. Among growth factors, only human growth hormone $(\mathrm{hGH})$ and the glucagon-like peptide-1 analogue liraglutide enhanced proliferation of rat beta cells, with a significant increase on both poly-L-lysine and ECM. By contrast, sorted adult human beta cells from 16 donors aged $48.9 \pm 14.3$ years (range 16-64 years) failed to replicate demonstrably in vitro regardless of the substratum or growth factors used.

Conclusions/interpretation These findings indicate that, in our conditions, the fully differentiated human adult insulinproducing beta cell was unable to proliferate in vitro. This has important implications for any attempt to expand cells from pancreases of donors of this age group. By contrast, the rat beta cells used here were able to divide in vitro, and this was enhanced by ECM, hGH and liraglutide.

Keywords Beta cells - Extracellular matrix .

Growth factors · Insulin secretion · Pancreatic islets .

Proliferation
Abbreviations
7-AAD 7-amino-actinomycin-D
BC-ECM bovine corneal endothelial extracellular matrix
CA19-9 carbohydrate antigen 19-9 


$\begin{array}{ll}\text { ECM } & \text { extracellular matrix } \\ \text { GLP-1 } & \text { glucagon-like peptide-1 } \\ \text { GSIS } & \text { glucose-stimulated insulin secretion } \\ \text { hGH } & \text { human growth hormone } \\ \text { JDRF } & \text { Juvenile Diabetes Research Foundation } \\ \text { KRBH } & \text { Krebs-Ringer bicarbonate HEPES buffer } \\ \text { NG } & \text { Newport Green } \\ \text { PDX1 } & \text { pancreatic and duodenal homeobox 1 } \\ \text { PLL } & \text { poly-L-lysine }\end{array}$

\section{Introduction}

As the availability of human donors for pancreatic islet transplantation is limited, there is an urgent need for alternative sources. In vitro expansion of adult human beta cells may provide an adequate source for beta cell therapy, but little is known about their proliferative capacity.

The extracellular matrix (ECM) is a complex structural entity surrounding cells within mammalian tissues that is able to regulate many essential cellular functions, including proliferation [1-4]. ECM produced by $804 \mathrm{G}$ (rat bladder carcinoma) cells thus improves glucose-stimulated insulin secretion (GSIS) and survival of primary rat beta cells [5-7]. Furthermore, this ECM or its human equivalent (HTB9ECM) increases replication of human endocrine islet and/or duct cells [8-11].

Several growth factors have been shown to be mitogenic for insulinoma cell lines [12-16], but their ability to promote replication of adult beta cells has been less extensively studied. The focus of this study was to understand whether adult beta cells can replicate in vitro, and if so whether this can be enhanced by ECM and growth factors.

\section{Methods}

Rat islet isolation and beta cell purification Animal experimentation conformed to the guide for the care and use of laboratory animals and was authorised by the Veterinarian Office of Canton de Geneve (Geneva, Switzerland). Islets were isolated by collagenase digestion of pancreases from 2- or 18-month-old male Wistar rats (Janvier, Le Genest-St-Isle, France), followed by Ficoll purification as described [17]. Islets were trypsinised and beta cells purified using a FACStar-Plus (Becton Dickinson, Sunnyvale, CA, USA) as described [18, 19] by autofluorescence or by virtue of their zinc content using the zinc-binding fluorochrome Newport Green (NG).

Human beta cell purification Human islets (average age of cadaveric donors $48.9 \pm 14.3$ years; range $16-64$ years; $n=16$ ) were provided through the Juvenile Diabetes Research
Foundation (JDRF) Islet Distribution Program by Islet Cell Resource Centers in Geneva (Switzerland), Milan (Italy) and Lille (France). The use of human tissue for research was approved by our local institutional ethical committee.

Single cell suspensions were obtained by incubating $\left(37^{\circ} \mathrm{C}\right.$, $10 \mathrm{~min}$ ) islets in Accutase (PAA Laboratories $\mathrm{GmbH}$, Colbe, Germany). The dispersed cells were washed with modified Krebs-Ringer bicarbonate HEPES buffer (KRBH: $125 \mathrm{mmol} / \mathrm{l} \mathrm{NaCl}, 4.74 \mathrm{mmol} / \mathrm{l} \mathrm{KCl}, 1 \mathrm{mmol} / 1 \mathrm{CaCl}_{2}$, $1.2 \mathrm{mmol} / 1 \mathrm{KH}_{2} \mathrm{PO}_{4}, 1.2 \mathrm{mmol} / 1 \mathrm{MgSO}_{4}, 5 \mathrm{mmol} / 1 \mathrm{NaHCO}_{3}$, $25 \mathrm{mmol} / 1$ HEPES, pH 7.4, 0.5\% BSA) containing $2.8 \mathrm{mmol} / \mathrm{l}$ glucose and resuspended in this buffer. Cells were incubated $\left(1 \mathrm{~h}, 4^{\circ} \mathrm{C}\right)$ with mouse anti-pan-ductal membrane carbohydrate antigen 19-9 (CA19-9) antibody $(1 \mu \mathrm{g} / \mathrm{ml}$; NovoCastra, Newcastle upon Tyne, UK), rinsed twice with KRBH and reincubated for $1 \mathrm{~h}$ with Alexa-Fluor 633 anti-mouse IgG (Santa Cruz Biotechnology, Santa Cruz, CA, USA). After washing, cells were resuspended in KRBH containing $1.5 \mu \mathrm{l} / \mathrm{ml}$ Pluronic F127 and incubated (30 min, $37^{\circ} \mathrm{C}$ ) with $1 \mu \mathrm{mol} / 1$ NG-PDX-Ac (Molecular Probes, Leiden, The Netherlands). After washing, cells were stained $10 \mathrm{~min}$ with 7-amino-actinomycin-D (7-AAD, $10 \mu \mathrm{g} / \mathrm{ml}$; Molecular Probes). Analysis and cell sorting were performed using a FACSvantage (Becton Dickinson). Beta cells were enriched in the 7-AAD-negative, CA19-9-negative and NGbright populations.

ECMs ECM from 804G cell-conditioned medium was prepared and used as described previously [6]. For lawns of lysed cells, HTB9 (human bladder carcinoma) cells were grown to confluency and then lysed by exposure for $10 \mathrm{~min}$ to $0.1 \mathrm{~mol} / 1 \mathrm{NH}_{4} \mathrm{OH}$ followed by washes with $\mathrm{H}_{2} \mathrm{O}$ (adapted from [20]). Coated Petri dishes were stored at $4^{\circ} \mathrm{C}$ after airdrying. Before use, dishes were washed once again and dried. Bovine corneal ECM (BC-ECM)-coated plasticwares were from Biological Industries (Kibbutz Beit Haemek, Israel). Dishes coated with poly-L-lysine (PLL; $100 \mu \mathrm{g} / \mathrm{ml}$ ) were used as control.

Culture of cells Culture medium for rat beta cells was DMEM (Gibco, Invitrogen, Basel, Switzerland), 10\% FCS, $11.2 \mathrm{mmol} / \mathrm{l}$ glucose, $1 \mathrm{mmol} / 1$ sodium pyruvate, $110 \mathrm{U} / \mathrm{ml}$ penicillin, $110 \mu \mathrm{g} / \mathrm{ml}$ streptomycin and $50 \mu \mathrm{g} / \mathrm{ml}$ gentamicin. For human beta cells, medium was CMRL 1066, 10\% FCS, $1 \%$ glutamine, $5.6 \mathrm{mmol} / 1$ glucose, $1 \mathrm{mmol} / 1$ HEPES and antibiotics as above. Sorted cells were washed with appropriate medium and incubated $\left(20 \mathrm{~h}, 37^{\circ} \mathrm{C}\right)$ in non-adherent $100 \mathrm{~mm}$ diameter Petri dishes to allow recovery from cell purification. Cells were resuspended at $4 \times 10^{5}$ cells $/ \mathrm{ml}$ in medium, and $50 \mu \mathrm{l}$ droplets deposited on coated dishes. Intact human islets were similarly deposited as droplets (ten islets per dish). In each instance, after $24 \mathrm{~h}, 2 \mathrm{ml}$ culture medium were added to the droplets. 
Immunofluorescence Sorted cells were attached $(90 \mathrm{~min})$ to PLL-coated Cunningham's chambers and then fixed (4\% paraformaldehyde [wt/vol.], $20 \mathrm{~min}$ ). After washing (PBS), cells were incubated (PBS $/ 0.5 \%$ Triton X-100 [wt/vol.], $4 \mathrm{~min}$ ), rinsed (PBS), preincubated (30 min, room temperature) in PBS $/ 0.5 \%$ BSA (wt/vol.) and exposed for $2 \mathrm{~h}$ (room temperature) to guinea pig anti-insulin serum (DB, University of Geneva, Switzerland) and rabbit anti-glucagon antibody (Dako, Baar, Switzerland). After three washes they were incubated ( $1 \mathrm{~h}$, room temperature) with FITCconjugated goat anti-rabbit or rhodamine-conjugated goat anti-guinea pig antibodies diluted in PBS/ $0.5 \%$ BSA (wt/vol.). Samples were examined by fluorescence microscopy (Carl Zeiss, Feldbach, Switzerland).

Short-term GSIS Beta cells were washed three times with $\mathrm{KRBH}, 2.8 \mathrm{mmol} / \mathrm{l}$ glucose and preincubated $\left(1 \mathrm{~h}, 37^{\circ} \mathrm{C}\right)$ with this same buffer, followed by successive $1 \mathrm{~h}$ incubations at $37^{\circ} \mathrm{C}$ in $\mathrm{KRBH}$ with 2.8 and $16.7 \mathrm{mmol} / 1$ glucose for rat beta cells or $22.2 \mathrm{mmol} / \mathrm{l}$ glucose for human beta cells. When indicated, growth factors were added directly in $\mathrm{KRBH}$ containing $16.7 \mathrm{mmol} / \mathrm{l}$ glucose. Cellular insulin was extracted with acid-ethanol, and insulin in buffers and extracts measured by RIA with rat or human insulin as the standard. Total insulin is the sum of extracted insulin and insulin secreted during the two incubations.

Detection of proliferation by immunofluorescence Islets or sorted beta cells were incubated with $10 \mu \mathrm{mol} / \mathrm{l} \mathrm{BrdU}$ for 1-6 days. They were fixed (1\% paraformaldehyde [wt/vol.], $1 \mathrm{~h}$ room temperature) and DNA denatured $(1.5 \mathrm{~mol} / \mathrm{l} \mathrm{HCl})$. After permeabilisation (PBS/0.5\% Triton X-100 [wt/vol.], $4 \mathrm{~min}$ ), proliferation was estimated using an immunohistochemical assay kit as described by the manufacturer (BrdU Labelling and Detection Kit; Roche, Basel, Switzerland). For Ki-67 staining, cells were fixed after 2-9 days of culture, washed (PBS), permeabilised (PBS/0.1\% Triton X-100 [wt/ vol.], $10 \mathrm{~min}$ ), rinsed (PBS), preincubated (30 min, room temperature) in $\mathrm{PBS} / 1 \% \mathrm{BSA}$ (wt/vol.) and stained with mouse anti-Ki-67 (BD Pharmingen, Basel, Switzerland) for $2 \mathrm{~h}$ (room temperature), followed by Alexa-fluor 533conjugated anti-mouse Ig. Cells were also co-stained for insulin or for pancreatic and duodenal homeobox 1 (PDX1; goat anti-PDX1; kind gift from C. V. Wright, Vanderbilt University, Nashville, TN, USA). Following washing, cells were incubated with Alexa-fluor 488-conjugated anti-guinea pig or anti-goat Ig. Nuclei were stained with $10 \mu \mathrm{g} / \mathrm{ml}$ DAPI (Sigma-Aldrich, Buchs, Switzerland). The percentage of cells double-positive for insulin+BrdU or PDX1+BrdU per total number of insulin- or PDX1-single-positive cells, respectively, was calculated.

To study effects of exogenous growth factors, beta cells were cultured for 1-5 days with $40 \mathrm{nmol} / 1$ of the long-acting glucagon-like peptide-1 (GLP-1) analogue liraglutide, $0.5 \mu \mathrm{g} / \mathrm{ml}$ EGF, $2 \mu \mathrm{mol} / 1$ gastrin, $400 \mathrm{ng} / \mathrm{ml}$ human growth hormone (hGH) (the generous gift of Novo Nordisk, Bagsvaerd, Denmark; concentrations were as recommended by the supplier and in the range of concentrations used by others [21]) and $2 \mathrm{nmol} / \mathrm{l}$ betacellulin (Sigma Buchs; a concentration that had been shown to increase DNA synthesis in human fetal islet-like cell clusters [22]).

Data analysis Data are means \pm SEM for $n$ independent experiments (using cells from separate islet isolations) unless specified otherwise. Statistical significance was tested by Student's unpaired $t$ test with $p<0.05$ considered significant.

\section{Results}

Effect of ECM on rat beta cell proliferation To study the impact of ECM on proliferation, rat beta cells were plated on $804 \mathrm{G}-\mathrm{ECM}$ or PLL (control), using standard culture conditions (DMEM, 10\% FCS, $11.2 \mathrm{mmol} / \mathrm{l}$ glucose). Beta cell proliferation was then measured by BrdU incorporation followed by immunostaining for BrdU and insulin or PDX1. Rat beta cells that had divided (BrdU-positive) continued to store insulin (Fig. 1a) and to express PDX1 (Fig. 1b) and they proliferated on both substrates. Interestingly, 804G-ECM significantly increased proliferation of rat beta cells at all times vs PLL (Fig. 1c).

Before performing similar experiments on human beta cells, we determined the effect of lysed HTB9 lawns, an ECM used for human beta cells, on rat beta cell replication and GSIS. HTB9-ECM induced spreading of rat beta cells (data not shown) and GSIS was significantly increased to the same extent as for cells on 804G-ECM compared with PLL (Fig. 2a). HTB9-ECM also significantly increased the proliferation of rat beta cells vs PLL, but this increase was less than that induced by $804 \mathrm{G}-\mathrm{ECM}$ (Fig. 2b). Rat beta cells also proliferated in CMRL 1066, the medium routinely used for human beta cells (data not shown). Furthermore, BCECM increased spreading and proliferation of rat beta cells by $2.8 \pm 0.3$-fold compared with PLL $(p=0.005)$.

Purity of human beta cell preparations Since it proved impossible to obtain a suitably enriched population of human beta cells using the same (autofluorescence) method as for rat cells, we adapted and combined previously published techniques [23-25] for this purpose, neither of which proved satisfactory alone. After dissociation of islets, human ductal cells were specifically labelled using anti-CA19-9 antibody, beta cells were labelled with NG (due to their high zinc content) and dead cells were labelled with 7-AAD, which binds to DNA when cell membrane permeability is altered after cell death. Cells were then analysed by FACS. 

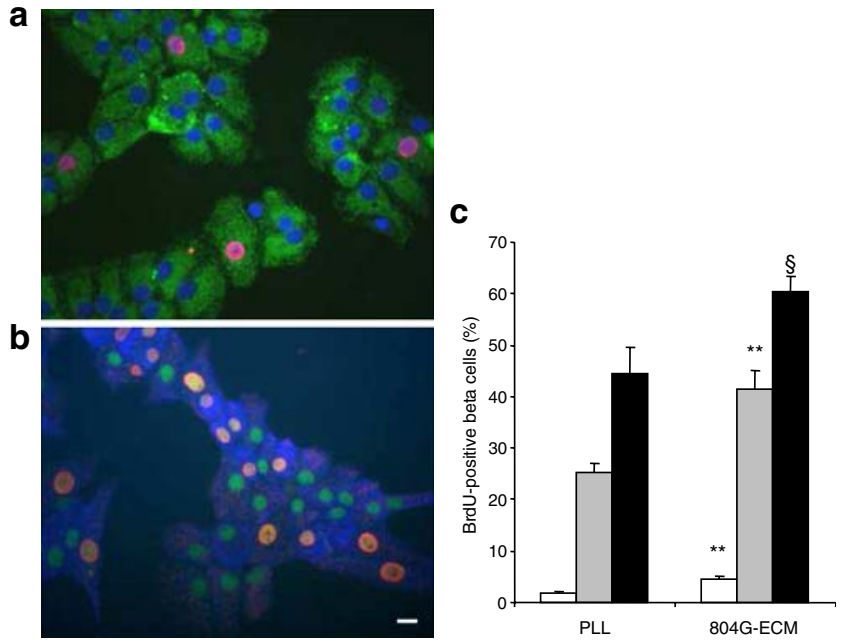

Fig. 1 Effect of $804 \mathrm{G}-\mathrm{ECM}$ on rat beta cell proliferation. Rat beta cells sorted by autofluorescence were attached to either PLL or 804G-ECM. After $24 \mathrm{~h}$ of culture (DMEM, 10\% FCS, $11.2 \mathrm{mmol} / 1$ glucose) cells were cultured for 1,4 or 6 days in the continuous presence of BrdU $(10 \mu \mathrm{mol} /$ 1). Immunofluorescence for BrdU (proliferation) and insulin (beta cells) was performed and the number of BrdU-positive beta cells was determined. a, b Representative micrographs of beta cells plated on $804 \mathrm{G}-\mathrm{ECM}$ incubated with BrdU for 2 or 4 days, respectively, and stained for BrdU (red nuclei in $\mathbf{a}$ and $\mathbf{b}$ ), insulin (green in $\mathbf{a}$ and blue in b) or PDX1 (green nuclei in b). Nuclei (blue in a) were stained with Hoechst 33342. Bar, $10 \mu \mathrm{m}$. c Quantitative data expressed as the percentage of insulin-positive cells that were also $\mathrm{BrdU}$ positive. Means \pm SEM, $n=3-4$ independent experiments; $* * p<0.01$ vs its respective PLL control; ${ }^{\S} p<0.03$ vs PLL control. White bars, 1 day; grey bars, 4 days; black bars, 6 days

After exclusion of 7-AAD- and C19-9-positive cells, two populations of cells were gated and sorted, according to their side scatter patterns and fluorescence (Fig. 3a): R5, high scatter/high NG fluorescence; R4, low scatter/low NG fluorescence. These sorted cell populations were analysed by immunofluorescence for insulin staining. The high NGpositive population (R5) appeared highly enriched in beta cells, while R4 was poor in beta cells (Fig. 3b), with other

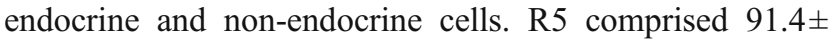
$2.8 \%$ insulin-positive and $3.9 \pm 2.5 \%$ glucagon-positive cells compared with $42.6 \pm 7.8 \%$ and $20.5 \pm 7.6 \%$, respectively, for the original unsorted cells $(n=7-9)$. Population R5, henceforth called 'human beta cells', survived well and showed very low levels of spontaneous apoptosis $(<1 \%$; not shown) after 10 days in culture.

To determine whether the NG sorting method could impact beta cell proliferation, rat beta cells sorted by this method were compared with those sorted by autofluorescence. Proliferation was similar and 804G-ECM significantly increased cell proliferation in both instances (Electronic supplementary material Fig.1).

Effect of ECM on human beta cell proliferation To study proliferation of sorted human beta cells we used plastic dishes coated with 804G-ECM, lysed HTB9 lawns or commercial BC-ECM as substrates. As for rat beta cells, human beta cells spread on all matrices tested (HTB9-, 804G- or BC-ECM), contrary to beta cells plated on PLL, which remained round. However, unlike for rat cells, GSIS was similar for human beta cells plated on PLL or on these different matrices (Fig. 4a). Furthermore, no cell replication was observed in human beta cells under any of these conditions (Fig. 4b), despite assays being performed on five independent isolations with more than 300,000 beta cells analysed. These experiments were performed with CMRL 1066 medium complemented with $10 \%$ FCS generally used for culturing human islets. However, we also investigated human beta cell replication in RPMI and DMEM medium containing $10 \%$ FCS or $2 \%$ human serum, and again no beta cell proliferation was detected (data not shown).

To test whether sorting of human beta cells affects their proliferation, we measured beta cell replication in isolated human islets that had not been trypsinised (intact) and where beta cells are in a more physiological environment. Figure 5 shows a representative experiment of six experiments. After 2-3 days, some islets were spread on HTB9ECM while the majority remained intact. In such intact unspread islets, BrdU-positive cells were observed (Fig. 5a) but confocal microscopy revealed that these BrdU-positive cells were always insulin-negative (Fig. 5b). Similar results were obtained with spread islets and after trypsinisation of intact islets and attachment of the single cell suspension, with BrdU-positive cells being systematically insulinnegative (Fig. 5c; about 100,000 cells obtained from three different islet preparations were analysed).

To investigate the hypothesis that human beta cells can lose insulin labelling during replication (perhaps by degranulation), we labelled beta cells for PDX1, a transcription factor expressed by beta cells in adult islets. After
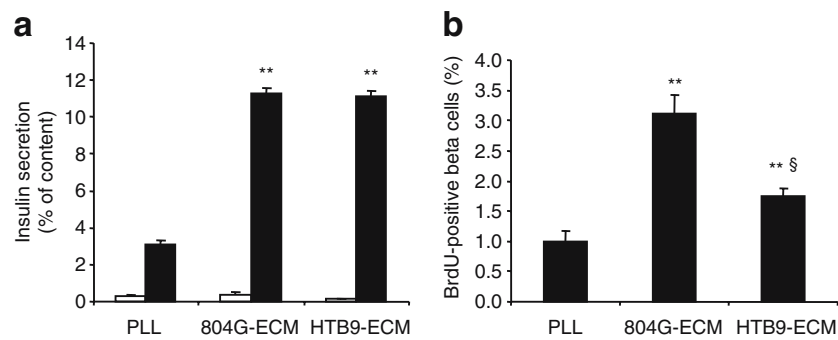

Fig. 2 Effect of HTB9-ECM on rat beta cell proliferation. Rat beta cells were attached to either PLL, 804G-ECM or lawns of $\mathrm{NH}_{4} \mathrm{OH}-$ lysed HTB9 cells (HTB9-ECM) and cultured for 2 days in DMEM, $10 \% \mathrm{FCS}, 11.2 \mathrm{mmol} / 1$ glucose, with the last day in the presence of $\operatorname{BrdU}(10 \mu \mathrm{mol} / \mathrm{l})$. a Short-term $(1 \mathrm{~h})$ insulin secretion in response to $2.8 \mathrm{mmol} / \mathrm{l}$ glucose (white bars) and $16.7 \mathrm{mmol} / \mathrm{l}$ glucose (black bars) was then analysed. Data (means \pm SEM of 3-4 independent experiments) are expressed as percentage of total (secretion plus content). b Beta cell proliferation. Means $\pm \mathrm{SEM}, n=3$ independent experiments. ${ }^{* *} p<0.01$ vs PLL control; ${ }^{\S} p<0.03$ vs 804 G-ECM 
Fig. 3 FACS analysis of human islet cells. a Single islet cells were stained with anti-CA19-9 antibody (ductal marker), NG (beta cells) and 7-AAD (dead cells) and analysed by FACS. Upper panel, 7-AAD; middle panel, $y$-axis CA19-9, $x$-axis NG; lower panel, gated NG vs side scatter after exclusion of 7-AAD- and CA19-9-positive cells. Cells were then sorted into NG-low (R4) and -bright (R5) subsets. b Immunofluorescence analysis of cells before and after sorting of the two subsets R4 and R5: insulin in green, nuclei in blue. Bar, $100 \mu \mathrm{m}$. SSC, side scatter pattern
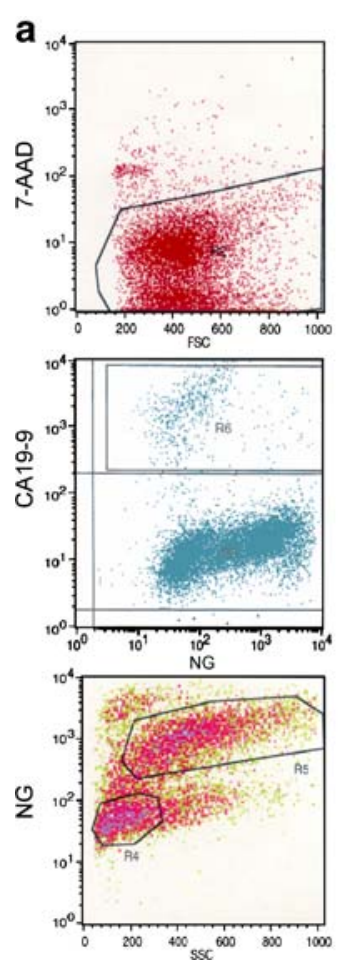

R4

b

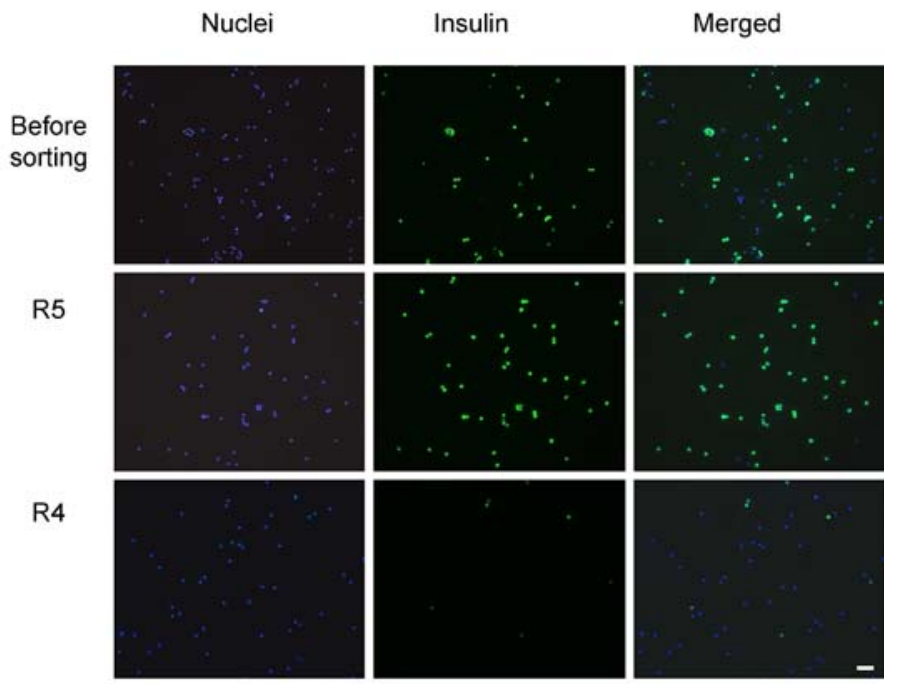

4 days in the presence of BrdU, we failed to observe any colocalisation between BrdU and PDX1 (Fig. 5d) either in $>500,000$ sorted beta cells or in approximately 200 intact islets obtained from four islet preparations that were evaluated in this regard.

With increasing culture time we observed the appearance of fibroblastoid- or mesenchymal-like cells with a large oval nucleus in sorted beta cells and in (unsorted) dispersed islet cell populations. Most of these cells were BrdUpositive (Fig. 5d) and were far more abundant in dispersed islet cells. These cells were systematically negative for insulin or PDX1.

Finally, we also stained human and rat beta cells with Ki-67 as an alternative means of identifying proliferating cells. As shown in Fig. 6a,b, after 48 h of culture on $804 \mathrm{G}-$ ECM, Ki-67-positive rat beta cells that continued to express insulin or PDX1 were detected. However, with sorted human beta cells or with human islets, cultured during 39 days, we could not observe coexpression of Ki-67 and insulin or PDX1 (Fig. 6c-f).

Effect of growth factors on beta cell proliferation and insulin secretion To try to stimulate beta cell proliferation, sorted beta cells as well as islets attached to ECM were incubated with betacellulin, EGF, gastrin, the GLP-1 analogue liraglutide or hGH for 1-10 days. Growth factors alone or in combination did not induce proliferation of human beta cells even in intact islets (data not shown; experiments were performed with eight different isolations). By contrast, hGH led to an approximately twofold increase of rat beta cell replication after $24 \mathrm{~h}$, in both cells plated on PLL and on 804G-ECM (Fig. 7a), while liraglutide, EGF, gastrin and betacellulin had no significant effect. EGF and betacellulin did, however, increase the growth of human mesenchymal-like cells (data not shown). However, when we extended the culture time to $48 \mathrm{~h}$, rat beta cell proliferation was significantly increased by liraglutide on PLL and on 804G-ECM (Fig. 7b). Nevertheless, even in the presence of hGH or the GLP-1 analogue, we still observed a significant increase of cell replication on 804G-ECM when compared with PLL, indicating an additive effect.

Since human beta cell replication could not be stimulated by the growth factors, it was possible that they were unresponsive in all respects to these agents. To investigate this, we tested their effect on insulin secretion. As expected, liraglutide significantly increased insulin secretion from both rat and human beta cells plated either on PLL or on the different matrices (Fig. 7c,d). For rat beta cells, hGH had a minor but significant effect on GSIS both on cells plated on PLL and on 804G-ECM (Fig. 7c).

Effect of age on rat beta cell proliferation To investigate the hypothesis that age can influence the proliferative capacity of beta cells, we also analysed beta cell proliferation from 18-month-old rats. Beta cells obtained from 18month-old rats proliferated in culture and 804G-ECM increased this proliferation $(0.84 \pm 0.37 \%$ BrdU-positive beta cells on PLL vs $2.87 \pm 0.1 \%$ on $804 \mathrm{G}-\mathrm{ECM} ; 24 \mathrm{~h}$ incubation with $\mathrm{BrdU}$; mean $\pm \mathrm{SD}, n=2$ independent experiments). However, in this limited series of experiments, beta 
a

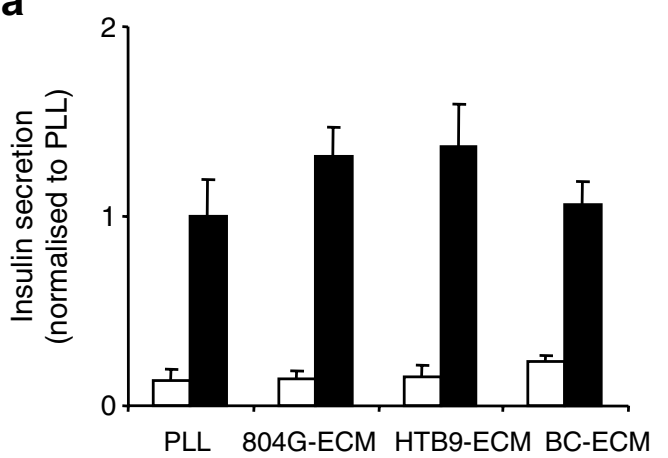

b
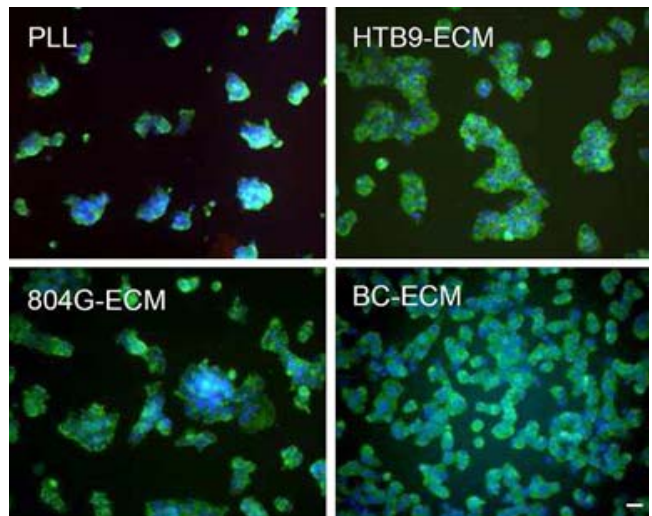

Fig. 4 Effect of ECM on sorted human beta cell proliferation. Sorted human beta cells were attached to Petri dishes coated with either PLL, 804G-ECM, lawns of $\mathrm{NH}_{4} \mathrm{OH}$-lysed HTB9 cells (HTB9-ECM) or BC-ECM. a After 3 days of culture, short-term (1 h) insulin secretion in response to $2.2 \mathrm{mmol} / 1$ glucose (white bars) and $22.2 \mathrm{mmol} / 1$ glucose (black bars) was then analysed. Results (insulin secretion as percentage total) are normalised to GSIS from cells on PLL, and expressed as means \pm SEM, $n=3-4$ independent experiments. b After 4 days in the continued presence of $\operatorname{BrdU}(10 \mu \mathrm{mol} / \mathrm{l})$, human beta cells were analysed by immunofluorescence for BrdU (red) and insulin (green). Results revealed that none of the insulin-positive cells are BrdUpositive (should be red). Nuclei (blue) were stained with Hoechst 33342. Bar, $30 \mu \mathrm{m}$

cells from these old rats did appear to proliferate less than those from young (8-week-old) rats both on PLL and on $804 \mathrm{G}-\mathrm{ECM}(1.96 \pm 0.01 \%$ and $4.85 \pm 0.97 \%$, respectively).

\section{Discussion}

In this study we describe a new technique using NG staining and autofluorescence-activated flow cytometry to obtain a $>90 \%$ pure and functional population of beta cells. Using this and an established method for sorting rat beta cells, we studied the effect of ECM in combination with growth factors on beta cell proliferation. In previous studies intact islets or islet cells more or less spread on ECM were used to examine beta cell replication. In these conditions, overlay of cells can lead to ambiguous labelling. Indeed the report that human beta cells are able to replicate when exposed to selected matrices and growth factors [26] was challenged by others showing that these culture conditions were mitogenic for duct cells and not for beta cells [11]. Using sorted human beta cells, and regardless of the culture conditions (various ECMs with or without growth factors), we failed to observe, according to our criteria, any bona fide beta cells that are Ki-67-positive or that had incorpo-

a
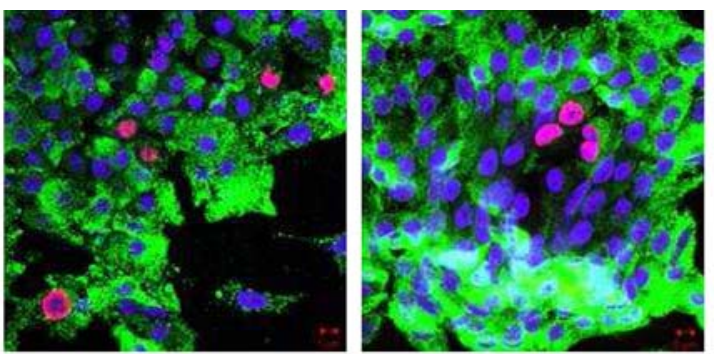

b
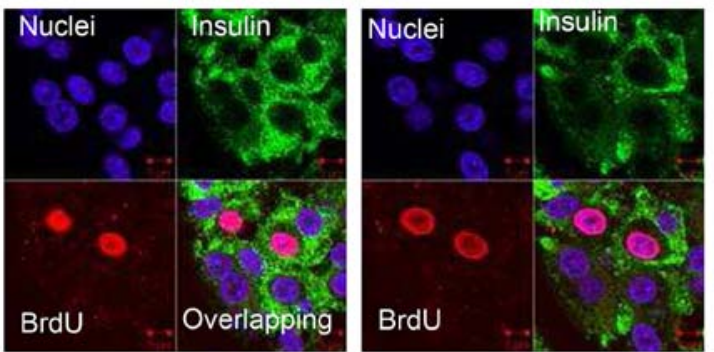

C

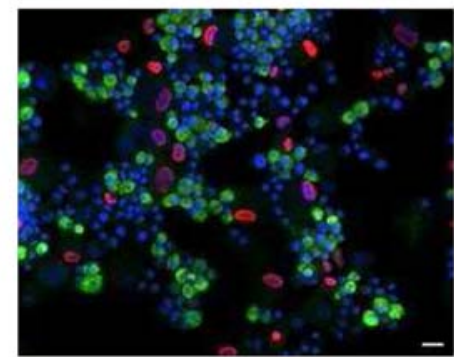

d
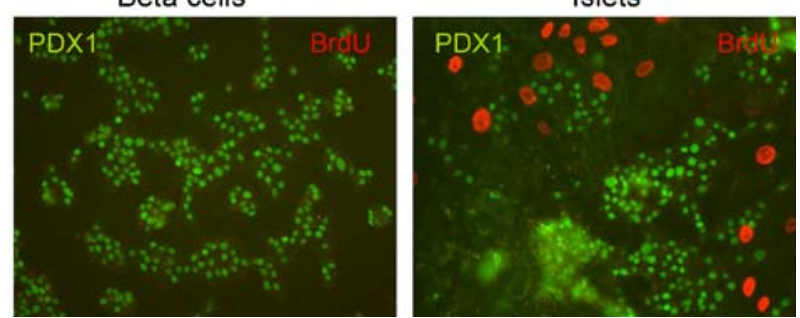

Fig. 5 Effect of ECM on beta cell proliferation in human islets or non-sorted human islet cells. a, b Intact human islets attached to HTB9-ECM and cultured for 9 days in the continued presence of $\operatorname{BrdU}(10 \mu \mathrm{mol} / \mathrm{l})$. a Two examples of BrdU-positive cells present in an islet that had spread (left) or not (right) on HTB9-ECM. b One example of Z-stack analysis showing that BrdU-positive cells were insulin-negative. c Cell suspension obtained after trypsinisation of islets but without sorting. d Intact human islets or purified human beta cells cultured on HTB9-ECM for 5 days with $\operatorname{BrdU}(10 \mu \mathrm{mol} / \mathrm{l})$ present during the last 4 days. Images are confocal microscopy of immunofluorescence. a-c BrdU, red; insulin, green; nuclei (Hoechst 33342), blue. d BrdU, red; PDX1, green. Bar, $30 \mu \mathrm{m}$ 

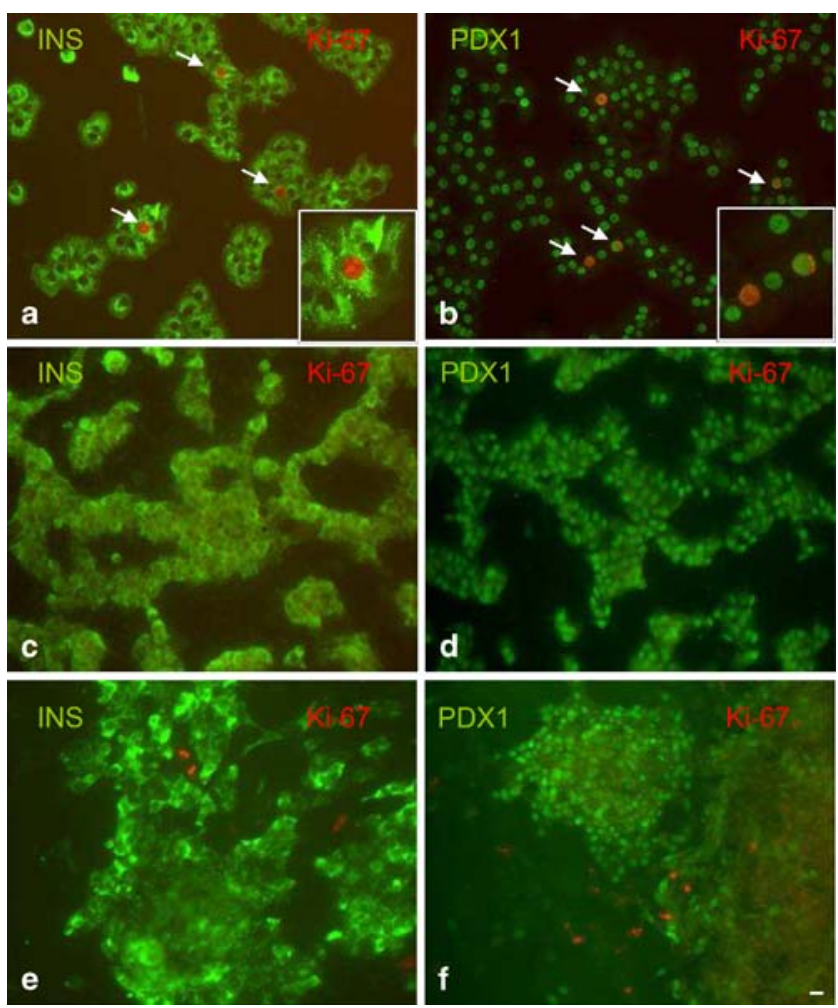

Fig. $6 \mathrm{Ki}-67$ expression in rat and human beta cells. Immunofluorescence for Ki-67 (a marker of proliferation, red in all pictures) and insulin (green in $\mathbf{a}, \mathbf{c}, \mathbf{e}$ ) or PDX1 (green in $\mathbf{b}, \mathbf{d}, \mathbf{f}$ ) was performed in rat beta cells plated on $804 \mathrm{G}-\mathrm{ECM}$ for $48 \mathrm{~h}(\mathbf{a}, \mathbf{b})$, and in sorted human beta cells $(\mathbf{c}, \mathbf{d})$ or human islets $(\mathbf{e}, \mathbf{f})$ plated on HTB9-ECM for 6 and 3 days, respectively. A number of cells displayed colocalisation of Ki-67 and PDX1 or insulin in rat beta cells (arrows in $\mathbf{a}, \mathbf{b}$; the boxes in lower right-hand corners are threefold magnifications of cells coexpressing insulin or PDX1 and Ki-67). Colocalisation of Ki-67 and PDX1 or insulin was not observed in human beta cells $(\mathbf{c}-\mathbf{f})$. Bar, $20 \mu \mathrm{m}$

rated BrdU even during prolonged ( $>10$ days) culture. We cannot exclude that an even longer time could be required for proliferation to be induced. However, and in striking contrast, beta cells from young rats were seen to proliferate in vitro and this was significantly increased by ECM and growth factors. The technique used to purify human beta cells is not the cause, because rat beta cells, purified with the same NG sorting method used for human cells, can proliferate in a similar manner to when sorted using the well-established autofluorescence method. Control experiments further indicated that neither the ECM nor the medium used for human beta cells was the cause. Furthermore, it was not possible to detect beta cell proliferation even in (intact) isolated human islets. To exclude the fact that division of human beta cells could be accompanied by rapid loss of insulin, we also performed double immunostaining of BrdU or Ki-67 and PDX1. But again no colocalisation of BrdU or Ki-67 with PDX1 was observed in human beta cells, in contrast to results obtained using rat beta cells.
The divergence between our data and those of Beattie et al. [8-10] may be explained in part, by differences in methods. In their studies, proliferation was on some occasions quantified by ${ }^{3} \mathrm{H}$-labelled thymidine incorporation, which determines the proliferation of all cells and not only beta cells. However, on other occasions proliferating cells were double-stained for insulin and BrdU [9] or Ki-67 [10]. As discussed above, however, even with confocal microscopy it is not easy to determine whether cells are truly doublelabelled or not if they are not in a veritable monolayer. Beattie et al. conclude that the cells they identify as doublepositive are never 'brightly stained' for insulin [9, 10], whereas upon close inspection of many such cells we consider them to be insulin-negative. In our study we did observe, as others in the past, a growing population of cells that were BrdU- or Ki-67-positive, but it was apparent by confocal microscopy that all of these cells were insulin or PDX1-negative. Moreover these cells that closely resemble the human islet-derived mesenchymal-like cells described by others $[27,28]$ were more abundant when we cultured dispersed islet cells rather than purified beta cells, suggesting that they did not derive from beta cells by epithelialmesenchymal transition [27]. This supports recent studies showing that mesenchymal cells emerging from mouse islets are similarly not derived from beta cells [29-32]. Nevertheless, we cannot exclude from our studies that in human beta cells proliferation is accompanied by the rapid loss of characteristic features such as PDX1 and insulin expression or that their expression is sufficiently attenuated as to make it undetectable in our immunofluorescence conditions. This issue could only be resolved by labelling human beta cells with a stable marker that is not lost upon de-differentiation. Double-positive cells (insulin and ductal markers) have been observed in healthy and pathological human pancreases [33]. These cells may represent newly differentiated ductal precursor cells as well as beta cells which have dedifferentiated towards a ductal precursor. Our technique for sorting beta cells would have excluded such cells, but had such cells proliferated in the unsorted islet cells or whole islet preparations they would have been scored as 'insulinpositive' cells, regardless of whether they also expressed ductal markers: no such cells were detected. However, interestingly, lineage tracing in mouse beta cells shows that de-differentiation occurs but is not followed by proliferation [32]. Furthermore, and although cells from 16 different human pancreases were studied, with thousands of cells screened in each preparation, we cannot exclude that adult human beta cells can replicate under our conditions at a nondetectably low rate or that other conditions may exist that might allow for such proliferation.

ECM has been reported to enhance proliferation of other cell types in vitro [34], but this is the first report to show that primary rat beta cell proliferation is significantly 

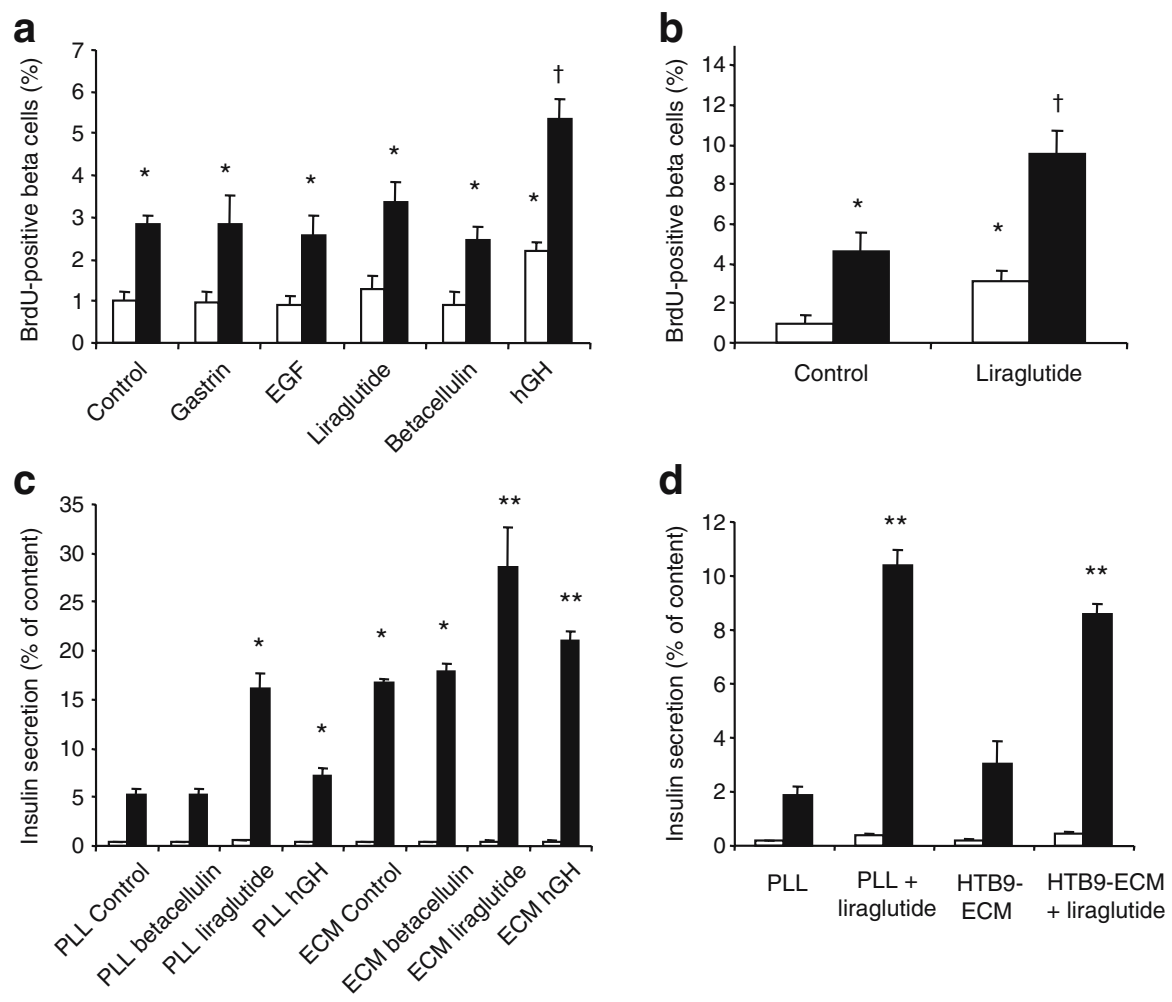

Fig. 7 Effect of growth factors on beta cell proliferation and insulin secretion. a, b Rat beta cells were attached to either PLL (white bars) or $804 \mathrm{G}-\mathrm{ECM}$ (black bars) and proliferation, measured as described in the legend to Fig. 1, was normalised to PLL. After an initial period of $24 \mathrm{~h}$, cells were cultured for $24 \mathrm{~h}$ with $\operatorname{BrdU}(10 \mu \mathrm{mol} / \mathrm{l})$ in the presence of different growth factors (a) or for $48 \mathrm{~h}$ in the presence of the GLP-1 analogue liraglutide with the last day in the presence of $\operatorname{BrdU}(10 \mu \mathrm{mol} / 1)$ (b). Means $\pm \mathrm{SEM}, n=3-5$ independent experiments; ${ }^{*} p<0.05$ vs PLL control; ${ }^{\dagger} p<0.05$ vs $804 \mathrm{G}-\mathrm{ECM}$ control. c After an initial period of $24 \mathrm{~h}$, rat beta cells were cultured on PLL or

increased by ECM. The signal transduction mechanism involved in this effect remains to be determined, but integrins could play a role in this phenomenon as has been demonstrated for insulin secretion [35].

Among the growth factors and hormones tested, only hGH and the GLP-1 analogue significantly increased adult rat beta cell proliferation. hGH levels rise during pregnancy and lactation, states that are associated with an expansion of the beta cell mass [36, 37], and hGH is one of the most potent mitogenic stimuli for rat beta cells even if its effect is greater in neonatal than in adult rat $[38,39]$. hGH was shown many years ago to stimulate human islet cell proliferation [38]. However, direct comparison with the present study is not possible for several reasons. First, incorporation of BrdU into all islet cells was quantified in the older study, without identification of cell type. Furthermore, only two human islet preparations were studied for their proliferation and $\mathrm{hGH}$ only increased proliferation in one. Although it is intriguing to note that these hGH-responsive islets were from a relatively young (16-year-old) female donor pancreas, while

on $804 \mathrm{G}-\mathrm{ECM}$ (ECM) for $24 \mathrm{~h}$ in the presence of different growth factors. Short-term $(1 \mathrm{~h})$ insulin secretion in response to $2.8 \mathrm{mmol} /$ 1 glucose (white bars) and $16.7 \mathrm{mmol} / 1$ glucose (black bars) in the presence of growth factors was then measured. Means \pm SEM, $n=3-4$ independent experiments; ${ }^{*} p<0.05$ vs PLL control; $* * p<0.01$ vs 804G-ECM control. d Short-term $(1 \mathrm{~h})$ insulin secretion of human beta cells in response to $2.2 \mathrm{mmol} / 1$ (white bars) and $22.2 \mathrm{mmol} /$ 1 glucose (black bars) in the presence of liraglutide was analysed after 3 days of culture with liraglutide. Means \pm SEM, $n=3$ independent experiments; $* * p<0.01$ vs its respective control

the other was from a 49-year-old female, it is impossible to draw any conclusions from such a limited sample set.

In our study, the GLP-1 analogue liraglutide significantly increased proliferation of rat beta cells only after $48 \mathrm{~h}$ but not $24 \mathrm{~h}$ of treatment, but instantly increased GSIS, in keeping with its well known insulinotrophic action [40-43]. Several in vitro studies have also shown that GLP-1 and its analogues are capable of inducing beta cell proliferation in rodent islets and insulinoma cell lines [14, 21, 41]. The proliferative effects of GLP-1 appear to involve multiple cellular pathways which may involve transcriptional induction of cyclin D1 [21]. Furthermore, GLP-1 also induces $P d x 1$ gene expression [44]. Taken together, GLP-1 could induce gene expression necessary for cell division, possibly explaining the need for a $48 \mathrm{~h}$ exposure to the hormone.

The effect of ECM on proliferation seemed to be additive to that of either hGH or liraglutide, suggesting an independent mode of action. In this study, betacellulin did not increase rat or human beta cell replication even though this member of the EGF family has been identified as a beta 
cell mitogen in INS-1 cells [16]. But in fact, in the rat RINm5F cell line, and also in fetal human beta cells, betacellulin failed to induce proliferation $[16,22]$, suggesting that the type and stage of development of the cells used can influence the outcome.

The discrepancy between the results obtained in rat and human beta cells, apart from an intrinsic species difference, could be explained by the age of the pancreas used for islet isolation (for most experiments, rat beta cells were obtained from 8-week-old animals whereas human beta cells were obtained from patients with an average age of 49 years). This hypothesis is supported by recent work from others demonstrating slower beta cell turnover in aged mice [45] or rats [46], and is favoured by our own results suggesting a lower proliferative capacity in beta cells isolated from 18-month-old rats even though the limited number of experiments does not allow for statistical analysis. Nevertheless, the old rat beta cells did proliferate in vitro in marked contrast to human beta cells (from all donors in the present study, spanning the range 16-64 years of age). Therefore, it seems that the observed discrepancy between rat and human beta cells probably reflects the combination of species as well as age differences. Regardless, the purpose of this study was not to compare beta cell proliferation from age-matched rat and human pancreases, but rather to evaluate the proliferative capacity of fully differentiated human beta cells from donors within the typical age range used for transplantation or experimental purposes. Rat beta cells were used as a positive control. Our (negative) results using human beta cells in our experimental setting have important implications for any attempt to expand cells from pancreases of donors of this age group (16-64 years).

In summary, rat beta cells can proliferate in vitro. This is significantly increased by ECM with a further additive increase by hGH and a GLP-1 analogue. Indeed and strikingly, after 6 days of continuous culture with BrdU, more than half of the cells on $804 \mathrm{G}-\mathrm{ECM}$ had become labelled with $\operatorname{BrdU}(60.44 \pm 3.08 \%, n=3)$, an extraordinarily high number for a fully differentiated cell type long considered essentially quiescent. By contrast, in this study using islets from cadaveric organ donors above the age of 16 years, we failed to detect replication of the fully differentiated human adult beta cell in vitro regardless of whether they had been sorted by FACS or not, and of the culture environment. While these negative data do not allow us to draw any conclusions regarding in situ beta cell regeneration in vivo in adult humans, and the possible beneficial effects of factors such as GLP-1 in such a context, they do have important implications for any attempt to grow such cells in culture with a view to obtaining increased numbers for transplantation.

Acknowledgements This work was supported by the JDRF Program for Regeneration of Beta Cell Function (Grant 1-2005-826). Human islets of Langerhans were provided by the Cell Isolation and Transplantation
Center at the University of Geneva School of Medicine, Switzerland, by the Department of Surgery, INSERM U859, Lille 2 University, Lille, France, and by the Islet Processing Facility, S. Raffaele Scientific Institute, Milan, Italy, thanks to the European Consortium for Islet Transplantation 'Islets for Research' Distribution Program sponsored by the JDRF. We thank C. Raveraud-Rouget for expert technical assistance, Novo Nordisk A/S for research support to T. Mandrup-Poulsen, N. Billestrup and C. Bruun, and A. E. Karlsen for the generous gift of the growth factors and hormones used in this study.

Duality of interest G. Parnaud, D. Bosco, T. Berney, F. Pattou, J. Kerr-Conte, M. Y. Donath, C. Bruun, N. Billestrup and P. Halban declare that there is no duality of interest associated with this manuscript. T. Mandrup-Poulsen is employed by Novo Nordisk and is also a shareholder and has received grants from Novo Nordisk.

\section{References}

1. Hisaoka M, Haratake J, Hashimoto H (1993) Pancreatic morphogenesis and extracellular matrix organization during rat development. Differentiation 53:163-172

2. Lelievre S, Weaver VM, Bissell MJ (1996) Extracellular matrix signaling from the cellular membrane skeleton to the nuclear skeleton: a model of gene regulation. Recent Prog Horm Res 51:417-432

3. Li S, Edgar D, Fassler R, Wadsworth W, Yurchenco PD (2003) The role of laminin in embryonic cell polarization and tissue organization. Dev Cell 4:613-624

4. Roskelley CD, Srebrow A, Bissell MJ (1995) A hierarchy of ECM-mediated signalling regulates tissue-specific gene expression. Curr Opin Cell Biol 7:736-747

5. Bosco D, Gonelle-Gispert C, Wollheim CB, Halban PA, Rouiller DG (2001) Increased intracellular calcium is required for spreading of rat islet beta-cells on extracellular matrix. Diabetes 50:1039-1046

6. Bosco D, Meda P, Halban PA, Rouiller DG (2000) Importance of cell-matrix interactions in rat islet beta-cell secretion in vitro: role of alpha6beta1 integrin. Diabetes 49:233-243

7. Hammar E, Parnaud G, Bosco D et al (2004) Extracellular matrix protects pancreatic beta-cells against apoptosis: role of short-and long-term signaling pathways. Diabetes 53:2034-2041

8. Beattie GM, Cirulli V, Lopez AD, Hayek A (1997) Ex vivo expansion of human pancreatic endocrine cells. J Clin Endocrinol Metab 82:1852-1856

9. Beattie GM, Montgomery AM, Lopez AD et al (2002) A novel approach to increase human islet cell mass while preserving betacell function. Diabetes 51:3435-3439

10. Beattie GM, Itkin-Ansari P, Cirulli V et al (1999) Sustained proliferation of PDX-1+ cells derived from human islets. Diabetes 48:1013-1019

11. Lefebvre VH, Otonkoski T, Ustinov J, Huotari MA, Pipeleers DG, Bouwens L (1998) Culture of adult human islet preparations with hepatocyte growth factor and $804 \mathrm{G}$ matrix is mitogenic for duct cells but not for beta-cells. Diabetes 47:134-137

12. Bai L, Meredith G, Tuch BE (2005) Glucagon-like peptide-1 enhances production of insulin in insulin-producing cells derived from mouse embryonic stem cells. J Endocrinol 186:343-352

13. Bernal-Mizrachi E, Wen W, Srinivasan S, Klenk A, Cohen D, Permutt MA (2001) Activation of Elk-1, an Ets transcription factor, by glucose and EGF treatment of insulinoma cells. Am J Physiol Endocrinol Metab 281:E1286-E1299

14. Buteau J, Foisy S, Joly E, Prentki M (2003) Glucagon-like peptide 1 induces pancreatic beta-cell proliferation via transactivation of the epidermal growth factor receptor. Diabetes 52:124-132 
15. Friedrichsen BN, Galsgaard ED, Nielsen JH, Moldrup A (2001) Growth hormone- and prolactin-induced proliferation of insulinoma cells, INS-1, depends on activation of STAT5 (signal transducer and activator of transcription 5). Mol Endocrinol 15:136-148

16. Huotari MA, Palgi J, Otonkoski T (1998) Growth factor-mediated proliferation and differentiation of insulin-producing INS-1 and RINm5F cells: identification of betacellulin as a novel beta-cell mitogen. Endocrinology 139:1494-1499

17. Sutton R, Peters M, McShane P, Gray DW, Morris PJ (1986) Isolation of rat pancreatic islets by ductal injection of collagenase. Transplantation 42:689-691

18. Rouiller DG, Cirulli V, Halban PA (1990) Differences in aggregation properties and levels of the neural cell adhesion molecule (NCAM) between islet cell types. Exp Cell Res 191:305-312

19. Van De Winkel M, Smets G, Gepts W, Pipeleers D (1982) Islet cell surface antibodies from insulin-dependent diabetics bind specifically to pancreatic B cells. J Clin Invest 70:41-49

20. Kato Y, Gospodarowicz D (1985) Effect of exogenous extracellular matrices on proteoglycan synthesis by cultured rabbit costal chondrocytes. J Cell Biol 100:486-495

21. Friedrichsen BN, Neubauer N, Lee YC et al (2006) Stimulation of pancreatic beta-cell replication by incretins involves transcriptional induction of cyclin D1 via multiple signalling pathways. J Endocrinol 188:481-492

22. Demeterco C, Beattie GM, Dib SA, Lopez AD, Hayek A (2000) A role for activin $\mathrm{A}$ and betacellulin in human fetal pancreatic cell differentiation and growth. J Clin Endocrinol Metab 85:3892-3897

23. Gmyr V, Belaich S, Muharram G et al (2004) Rapid purification of human ductal cells from human pancreatic fractions with surface antibody CA19-9. Biochem Biophys Res Commun 320:27-33

24. Ichii H, Inverardi L, Pileggi A et al (2005) A novel method for the assessment of cellular composition and beta-cell viability in human islet preparations. Am J Transplant 5:1635-1645

25. Lukowiak B, Vandewalle B, Riachy R et al (2001) Identification and purification of functional human beta-cells by a new specific zinc-fluorescent probe. J Histochem Cytochem 49:519-528

26. Hayek A, Beattie GM, Cirulli V, Lopez AD, Ricordi C, Rubin JS (1995) Growth factor/matrix-induced proliferation of human adult beta-cells. Diabetes 44:1458-1460

27. Gershengorn MC, Hardikar AA, Wei C, Geras-Raaka E, MarcusSamuels B, Raaka BM (2004) Epithelial-to-mesenchymal transition generates proliferative human islet precursor cells. Science 306:2261-2264

28. Ouziel-Yahalom L, Zalzman M, Anker-Kitai L et al (2006) Expansion and redifferentiation of adult human pancreatic islet cells. Biochem Biophys Res Commun 341:291-298

29. Atouf F, Park CH, Pechhold K, Ta M, Choi Y, Lumelsky NL (2007) No evidence for mouse pancreatic beta-cell epithelial-mesenchymal transition in vitro. Diabetes 56:699-702

30. Chase LG, Ulloa-Montoya F, Kidder BL, Verfaillie CM (2007) Islet-derived fibroblast-like cells are not derived via epithelialmesenchymal transition from $\mathrm{Pdx}-1$ or insulin-positive cells. Diabetes 56:3-7

31. Morton RA, Geras-Raaka E, Wilson LM, Raaka BM, Gershengorn MC (2007) Endocrine precursor cells from mouse islets are not generated by epithelial-to-mesenchymal transition of mature beta cells. Mol Cell Endocrinol 270:87-93

32. Weinberg N, Ouziel-Yahalom L, Knoller S, Efrat S, Dor Y (2007) Lineage tracing evidence for in vitro dedifferentiation but rare proliferation of mouse pancreatic beta-cells. Diabetes 56:1299-1304

33. Gmyr V, Kerr-Conte J, Belaich S et al (2000) Adult human cytokeratin 19-positive cells reexpress insulin promoter factor 1 in vitro: further evidence for pluripotent pancreatic stem cells in humans. Diabetes 49:1671-1680

34. Adams JC, Watt FM (1993) Regulation of development and differentiation by the extracellular matrix. Development 117 : 1183-1198

35. Parnaud G, Hammar E, Rouiller DG, Armanet M, Halban PA, Bosco D (2006) Blockade of beta1 integrin-laminin-5 interaction affects spreading and insulin secretion of rat beta-cells attached on extracellular matrix. Diabetes 55:1413-1420

36. Sorenson RL, Brelje TC (1997) Adaptation of islets of Langerhans to pregnancy: beta-cell growth, enhanced insulin secretion and the role of lactogenic hormones. Horm Metab Res 29:301-307

37. Parsons JA, Brelje TC, Sorenson RL (1992) Adaptation of islets of Langerhans to pregnancy: increased islet cell proliferation and insulin secretion correlates with the onset of placental lactogen secretion. Endocrinology 130:1459-1466

38. Brelje TC, Scharp DW, Lacy PE et al (1993) Effect of homologous placental lactogens, prolactins, and growth hormones on islet B-cell division and insulin secretion in rat, mouse, and human islets: implication for placental lactogen regulation of islet function during pregnancy. Endocrinology 132:879-887

39. Billestrup N, Nielsen JH (1991) The stimulatory effect of growth hormone, prolactin, and placental lactogen on beta-cell proliferation is not mediated by insulin-like growth factor-I. Endocrinology 129:883-888

40. Kieffer TJ, Habener JF (1999) The glucagon-like peptides. Endocr Rev 20:876-913

41. Drucker DJ (2003) Glucagon-like peptide-1 and the islet beta-cell: augmentation of cell proliferation and inhibition of apoptosis. Endocrinology 144:5145-5148

42. Drucker DJ (2003) Glucagon-like peptides: regulators of cell proliferation, differentiation, and apoptosis. Mol Endocrinol 17: 161-171

43. Brubaker PL, Drucker DJ (2004) Minireview: glucagon-like peptides regulate cell proliferation and apoptosis in the pancreas, gut, and central nervous system. Endocrinology 145:2653-2659

44. Buteau J, Roduit R, Susini S, Prentki M (1999) Glucagon-like peptide-1 promotes DNA synthesis, activates phosphatidylinositol 3kinase and increases transcription factor pancreatic and duodenal homeobox gene 1 (PDX-1) DNA binding activity in beta (INS-1)cells. Diabetologia 42:856-864

45. Teta M, Long SY, Wartschow LM, Rankin MM, Kushner JA (2005) Very slow turnover of beta-cells in aged adult mice. Diabetes 54:2557-2567

46. Maedler K, Schumann DM, Schulthess F et al (2006) Aging correlates with decreased beta-cell proliferative capacity and enhanced sensitivity to apoptosis: a potential role for Fas and pancreatic duodenal homeobox-1. Diabetes 55:2455-2462 